\title{
Impact of an Acute Sublethal Exposure of Endosulfan on Early Juvenile Lobster (Homarus americanus)
}

\author{
Dounia Daoud (Corresponding author) \\ Research Scientist for Homarus Inc. and EcoNov Inc. \\ Research associate Universite de Moncton \\ 408 rue Main St., Shediac, NB, E4P 2G1, Canada \\ Tel: 1-506-532-2485_E-mail: dounia@mfu-upm.com
}

\author{
Wayne L. Fairchild \\ Gulf Fisheries Centre, Fisheries and Oceans Canada \\ P.O. Box 5030, Moncton, NB, E1C 9B6, Canada \\ E-mail: Wayne.Fairchild@dfo-mpo.gc.ca
}

\begin{abstract}
Michel Comeau
Gulf Fisheries Centre, Fisheries and Oceans Canada

P.O. Box 5030, Moncton, NB, E1C 9B6, Canada

E-mail: Michel.Comeau@dfo-mpo.gc.ca
\end{abstract}

\begin{abstract}
Benoit Bruneau
Universite de Moncton and EcoNov Inc., campus de Moncton

Moncton, NB, E1C 3E9, Canada

E-mail: benoit.bruneau1@gmail.com
\end{abstract}

Martin D. Mallet

Homarus Inc. and EcoNov Inc.

408 rue Main St., Shediac, NB, E4P 2G1, Canada

E-mail: martin@mfu-upm.com 
Paula M. Jackman

Environment Canada

P.O. Box 23005, Moncton, NB, E1A 6S8, Canada

E-mail: Paula.Jackman@EC.GC.CA

\author{
Kadra Benhalima \\ Gulf Fisheries Centre, Fisheries and Oceans Canada \\ P.O. Box 5030, Moncton, NB, E1C 9B6, Canada \\ E-mail: Kadra.Benhalima@dfo-mpo.gc.ca
}

\author{
Panagiotis Berillis \\ Department of Ichthyology and Aquatic Environment, School of Agricultural Sciences \\ GR-38446 N, Ionia Magnisias, Greece \\ E-mail: pveril@apae.uth.gr
}

\begin{abstract}
Elena Mente
Department of Ichthyology and Aquatic Environment, School of Agricultural Sciences

GR-38446 N, Ionia Magnisias, Greece

E-mail: e.mente@abdn.ac.uk
\end{abstract}

Received: March 18, 2014 Accepted: April 11, 2014 Published: July 1, 2014

doi:10.5296/ast.v2i2.5575 URL: http://dx.doi.org/10.5296/ast.v2i2.5575

\begin{abstract}
Anthropogenic chemicals in the environment during critical periods could potentially affect the physiology of the economically valuable American lobster (Homarus americanus). Endosulfan (Thiodan ${ }^{\mathrm{TM}} \mathrm{WP}$ ) is a broad-spectrum organochlorine insecticide widely used in agricultural areas in Canada that significantly affects survival and growth of lobster larvae based on acute exposure studies. To detect more subtle physiological effects of an acute (96-h) sub-lethal level $\left(0.1 \mu \mathrm{g} \cdot \mathrm{L}^{-1}\right)$ of formulated endosulfan exposure on early juvenile lobsters, investigations of metabolic rates, growth and the tissue structure of the
\end{abstract}




\section{Macrothink

hepatopancreas were conducted on animals that molted following the exposure. The standard and active metabolic rates were not significantly affected, but their differential, defined as the metabolic scope (MS) was significantly decreased by $25 \%$ for exposed animals. Lobster growth and survival were not affected. For the exposed lobsters, minor alterations of the digestive cell structures were observed. These results suggest that the decrease in MS for exposed juvenile lobsters could have consequences in terms of survival in the wild by impairing their abilities to find a shelter, food or protect themselves from predators. The growth and survival in laboratory conditions suggests that lobsters may adjust their metabolism to pesticide exposure by maintaining a positive energy balance with some compensatory mechanisms; however, this may not be possible in their natural environment. This study suggests that conclusions based solely on lethal toxicity assays could be misleading for sublethal effects of contaminants on marine organisms, which could be investigated more thoroughly using an integrated approach based on physiological indicators.

Keywords: Endosulfan, Lobster, Growth, Histology, Metabolic rates, Oxygen consumption 


\section{Introduction}

Coastal commercial fishing grounds in the southern Gulf of St. Lawrence (sGSL), Canada, are subjected to high anthropogenic pressures, not only due to fishing activity but also as a consequence of pollution inputs from industry, agriculture and aquaculture at nearby coastal sites, which were identified as an emerging issue (DFO, 2010). The American lobster (Homarus americanus) is the most valuable fishery in Canada and after historically high landings in the late 1980s and early 1990s, stocks in most areas declined (Comeau et al., 2008). Although landings in general have since improved in the sGSL, mostly due to conservation measures and favorable ecosystem conditions, they have remained low within the Northumberland Strait where they are currently at their lowest level on record (Comeau et al., 2004; Comeau et al., 2008).

Little is known of the ability of invertebrates, lobsters in particular, to deal with anthropogenic environmental stressors (e.g. pesticides). Increasing concerns about the toxic effects of pesticides on non-target aquatic organisms have emerged (Ernst et al., 2001). In fact, increased interest in studies on toxicologic and metabolic effects of sublethal concentrations of specific contaminants including pesticides for lobsters began a decade ago after high mortalities in Long Island Sound (De Guise et al., 2005; Walker et al., 2005; Zulkosky et al., 2005). There has been no comprehensive analysis of the effect of pesticides on lobsters despite sufficient evidence that active ingredients of pesticides cause alteration of gene expression, behaviour, growth inhibition, survival, and histopathology on non-target organism like lobster (Fairchild et al., 2010; Horst et al., 2007; Magel et al., 2009; Walker et al., 2005; Walker et al., 2010) or other crustaceans (Ernst et al., 2001; Hellou et al., 2009; Reebs et al., 2011). Various chemicals used in aquaculture, such as sea-lice treatments in salmon aquaculture, have been proven to have potential deleterious effects on the lobster spawning population (Burridge et al., 2008) and on larval stages (Fairchild et al., 2010), both inferred from laboratory studies. Hence, lobster larvae and juvenile stages could be the most affected stages in a population exposed to contaminants.

Repeated fish kills events in the Maritime Provinces of Canada have received increasing public interest and were mainly related to pesticide contamination from agriculture (Gormley et al., 2005; Lakshminarayana et al., 1992). Endosulfan is an organochlorine insecticide and one of the most widely investigated pesticides in Canada, with high use in PEI and New Brunswick (NB) (Tuduri et al., 2006; White et al., 2006). It is used to control a number of insects in a variety of agricultural crops including intensive potato cultivation and one of the isomers (ß-endosulfan) tends to be highly persistent and bioaccumulative in the environment (CCME, 2010). It is found in soils and in the atmosphere, making drift issues a major environmental problem (Weber et al., 2010; White et al., 2006). Endosulfan was detected in freshwater streams in about $6 \%$ of the samples in 1-4 years over a 5-year period (2003-2007) in intensive potato production regions of PEI (Xing et al., 2012). Maximum endosulfan concentration in freshwater streams for PEI was about $10 \mu \mathrm{g} \cdot \mathrm{L}^{-1}$ with a highest annual mean of $0.64 \mu \mathrm{g} \cdot \mathrm{L}^{-1}$ which exceed endosulfan concentrations recommended by the Canadian Water Quality Guidelines for the protection of aquatic life (CCME, 2010), which is $0.09 \mu \mathrm{g} \cdot \mathrm{L}^{-1}$ for a short-term exposure in marine water or $0.06 \mu \mathrm{g} \cdot \mathrm{L}^{-1}$ for freshwater. Endosulfan is known to be 
highly toxic to aquatic invertebrates (Lombardi et al., 2001; Wirth et al., 2001), but studies of its effect on lobster are limited.

Exposure of aquatic organisms to anthropogenic chemical stressors can impair energy assimilation and conservation, as well as increase basal metabolic demand leading to reduction in net energy balance (Baird et al., 1990). The resulting energy deficit may have adverse effects on survival, growth, and reproduction. For lobster larvae, it was shown that exposure to alkylphenols, endocrine disrupters, could significantly reduce survival and growth (Laufer et al., 2012). Metabolic rates (MR) could represent a good indicator to reflect physiological dysfunction. As such, oxygen consumption has been commonly used as a proxy for metabolic rate in aquatic and terrestrial animals. The scope for growth (SfG) integrates physiological, cellular and biochemical changes for the whole animal and provides a robust tool for measuring its performance under stress, and therefore to infer to the population fitness. SfG has been shown to decrease due to a variety of stressors including temperature, salinity and pollution in a suite of marine and freshwater invertebrates (Verslycke et al., 2004). Similarly, metabolic scope (MS; also called aerobic scope) is one of the most integrative approaches under experimental conditions to evaluate potential effects of pesticides at a population level. The MS for activity, defined as the difference between active (AMR) and standard (SMR) metabolic rates, gives a measure of the surplus energy available for aerobic activities beyond that of biological maintenance (Fry, 1971), such as growth, swimming or feeding activities.

The digestive gland structure and functions are strongly affected by endosulfan (Bhavan \& Geraldine, 2000; Wu et al., 2008; Yadwad, 1992). The digestive gland is thus commonly used as a target organ in environmental pollution assessment in marine animals (Giambérini \& Cajaraville, 2005; Zaldibar et al., 2007; Zorita et al., 2006). Short-term exposure or pulse-exposure was thought to be more environmentally relevant exposure for this study, regarding endosulfan's potential half-life in water and the typical patterns of endosulfan application to fields (Beyger et al., 2012).

The present study investigates sublethal effects of endosulfan exposure on the metabolic rate of juvenile American lobsters. We also measured its effect on growth and the cell physiology of the hepatopancreas to determine if physiological alterations could be correlated with metabolic changes. We hypothesized that lobsters exposed to organochlorines reduce their energy reserves, which could lead to reduced fitness for the population. This is the first time that the effect of endosulfan on metabolism is investigated for a crustacean using long-term measurements of oxygen consumption with an intermittent-flow system.

\section{Materiel and Methods}

\subsection{Animal Maintenance}

Newly hatched stage I larvae were transferred $250 \mathrm{~km}$ from the Coastal Zones Research Institute located in Shippagan, Canada, to Environment Canada (EC) laboratory in Moncton. They were communally raised to stage IV in $150 \mathrm{~L}$ tanks with a minimum renewal of $20 \mathrm{~L}$ of filtered seawater daily $\left(\mathrm{T}=20^{\circ} \mathrm{C}, \mathrm{S}=28 \%\right.$ ) and fed a combination of live Artemia (Salt 
Creek, Select Brand Artemia cists), dry food (Salt Creek, brine shrimp flakes) and frozen Artemia (Hikari, Kyorin Co. Ltd.) every day. When they reached stage IV, post-larvae were separated to avoid cannibalism and individually placed in $1 \mathrm{~L}$ glass test vessels. They were fed a daily combination of dry food and frozen Artemia, with an $80 \%$ water renewed three times a week until the beginning of the experiments.

\subsection{Endosulfan Exposure}

Juvenile lobsters cephalothorax length (CL) between 4.35 and $7.94 \mathrm{~mm}$ that were 5 to 15 days postmolt were randomly selected and exposed for $96 \mathrm{~h}$ to formulated endosulfan (Thiodan ${ }^{\mathrm{TM}}$ WP) at a concentration of $0.1 \mu \mathrm{g} \cdot \mathrm{L}^{-1}$ (exposed group) or maintained in seawater (control group). The exposure concentration $0.1 \mu \mathrm{g} \cdot \mathrm{L}^{-1}$ for $96 \mathrm{hr}$ was chosen in accordance with prior trials in the EC laboratory and CCME guidelines, and was near the very low end of the species sensitivity distribution for marine fish and invertebrates (CCME, 2010). As expected, no mortality was observed during and immediately following endosulfan exposure. Lobsters were individually placed in 1-L glass vessels and tests were conducted under static conditions with gentle aeration provided through glass pipettes giving approximately 100 bubbles per minute. Fluorescent lighting was maintained at 100-500 lux on a 16:8 light:dark cycle throughout the trial. Temperature (hand held glass thermometer containing alcohol), dissolved oxygen (YSI Model 58 DO meter with a YSI Model 5905 BOD probe), pH (Accumet AB15 pH meter) and salinity (Reichert model 13104190) were measured and verified every day. Lobsters were fed daily a combination of dry Artemia flakes and frozen Artemia and water was not renewed during the exposure procedure.

Metabolic rate determinations and histology of the hepatopancreas were conducted in 2010, whereas growth experiments were conducted in 2011 due to lobster availability and logistic limitations. Endosulfan exposures and experimental conditions were the same in both years (Table 1).

Table 1. Allocation of available juvenile lobster to endpoints in 2010 and 2011 for control and exposed to formulated endosulfan $\left(0.1 \mu \mathrm{g} \cdot \mathrm{L}^{-1}\right)$ for $96 \mathrm{~h}$

\begin{tabular}{|c|c|c|c|c|}
\hline & \multicolumn{2}{|l|}{2010} & \multicolumn{2}{|l|}{2011} \\
\hline & Control & Exposed & Control & Exposed \\
\hline Total number used in endosulfan exposures & 49 & 49 & 31 & 31 \\
\hline $\begin{array}{l}\text { Portion to Qualitative and Quantitative Histology (A1) } \\
\text { (after the } 96 \text { h exposure) }\end{array}$ & $10 / 49$ & $12 / 49$ & - & - \\
\hline $\begin{array}{l}\text { Portion to Metabolism (B) } \\
\text { (SMR, MMR and MS) }\end{array}$ & $12 / 49$ & $15 / 49$ & - & - \\
\hline $\begin{array}{l}\text { Portion to Qualitative and Quantitative Histology (A2) } \\
\text { (after metabolic measurements) }\end{array}$ & $10 / 49$ & $14 / 49$ & - & - \\
\hline Portion to Growth $(\mathbf{C})$ & - & - & $25 / 31$ & $25 / 31$ \\
\hline $\begin{array}{l}\text { Portion to Descriptive Histology (D) } \\
\text { (after the } 96 \text { h exposure) }\end{array}$ & - & - & $6 / 31$ & $6 / 31$ \\
\hline Remaining unsampled lobster larvae & $27 / 49$ & $22 / 49$ & $0 / 31$ & $0 / 31$ \\
\hline
\end{tabular}


In 2010, a total of 49 juveniles were used for exposure and control conditions. Two groups for histology observations were considered: animals sacrificed immediately after the $96 \mathrm{~h}$ toxicity exposure procedure (group A1) and lobsters that spent an additional 4-5 days in metabolic chambers after the exposure before being sacrificed for histology (group A2). Group A1 consisted of 22 randomly sub-sampled juveniles (10 control and 12 exposed) whereas the remaining animals were transferred and maintained in clean sea-water. From this group, randomly sub-sampled juveniles (12 control and 15 exposed) were used for metabolic rate measurements (group B) before being sacrificed for histology observations (group A2). In 2011, 31 juvenile lobsters were used for exposure or control conditions. Growth was monitored after exposures until subsequent molt occurred (group C), whereas a group was sampled immediately after exposure for histology observations (group D) (Table 1).

\subsection{Measurement of Oxygen Consumption and Determination of Metabolic Rates}

Intermittent-flow respirometry was conducted in a serial closed-system (Daoud et al., 2007). Briefly, four chambers were connected allowing for measurements of oxygen consumption from four lobsters simultaneously. During each cycle, when the system was closed, lobster respiration was analyzed by measuring the decrease in oxygen level. Regardless to 2007 protocol, an optode was used. It is a type of sensor that relies on the ability of oxygen to act as a dynamic luminescence quencher (Tengberg et al., 2006). A specific non-invasive adaptation of these sensor probes, which consisted of fixing sensor spots (PreSens, Germany) on the inner surface of the glass chambers, was used. Each loop (chamber and tubing) had a volume of $6 \mathrm{ml}$. To monitor dissolved oxygen, the optodes were connected to an oxymeter (OXY-4; PreSens, Germany) and then to a computer. An online temperature compensation device (TEMP-4; Loligo Systems, Denmark) connected to the oxymeter added a real-time temperature compensation of oxygen data. An electronic device controlled all compounds of the loop (Autoresp4; Loligo Systems, Denmark).

At the beginning of each session, randomly selected lobsters from the toxicity exposure procedures (group B) were forced to swim to exhaustion (at least $25 \mathrm{~min}$.) in a beaker where a magnetic agitator created a current. Briefly, the water current speed was gradually increased until maximum activity. When exhaustion was apparent, as indicated by an inability to swim and a tendency to rest against the bottom, lobsters were immediately transferred to the chambers and oxygen consumption was measured as described above.

For each chamber, specific background respiration was determined by completing three cycles without a lobster at the beginning and the end of each session. A randomly allocated empty chamber (blank chamber) was also used for the entire duration of a session in order to monitor trends in background respiration. A combination of exposed-control lobsters and the empty chamber was randomly allocated to each chamber for each session. Each session consisted of a succession of cycles that was lasting 4-5 days to insure that animals reached their lowest metabolic rate. At the end of each cycle $(700 \mathrm{sec})$, water was flushed from each of the four chambers using a submersible large pump (Eheim, model 1046-80 GPH) for 300 sec, after which dissolved oxygen in the chambers was close to saturation. A waiting period $(150 \mathrm{sec})$ allowed probes to stabilize before oxygen was measured in the chambers for 250 
sec. Dissolved oxygen was never less than $90 \%$ saturation at the end of a measurement period. Every morning, optodes were calibrated at 100\% oxygen saturation. Nitrogen gas was used to calibrate the $0 \%$ at the beginning of the experiment. Barometric pressure, temperature and salinity in the experimental tank were noted every morning and used to calculate solubility of oxygen. A total of ten sessions were conducted during the whole experiment.

\subsection{Histology of the Hepatopancreas}

Juvenile lobsters (control and exposed) from 2010 (group A1, A2) and 2011 (D) were fixed in Bouin's fluid prior to standard histological preparation. Four slides were prepared for each lobster ( 4 serial sections of 5 to $6 \mu \mathrm{m}$ ), all slides were stained with Masson's trichrome (Gabe, 1968) and examined on an Olympus BX51 compound light microscope and images were captured with a colour digital camera ImagePro ${ }^{\circledR}$ program.

The surface area and the ratio of B-, F-, R-cells, and the lumen in the corresponding surface area of the hepatopancreas tubule were automatically calculated using light microscope images of histological sections of the digestive gland (Berillis et al., 2013).

\subsection{Measurement of Growth}

Information on growth was collected for exposed and control animals following the 2011 endosulfan exposures. Initial or pre-molt $\mathrm{CL}\left(\mathrm{CL}_{\mathrm{i}} \pm 0.01 \mathrm{~mm}\right)$ was measured after the exposures to avoid stress. Following the exposure, lobsters (group C) were individually placed in clean 1-L glass vessels to follow their growth through a complete molt cycle. Lobsters were monitored daily for molts and survival. Newly molted lobsters were measured (post-molt or $\mathrm{CL}_{\mathrm{f}}$ ). The $\mathrm{CL}$ was measured using a digital microscope (Vp-Eye ver. 6.0, Aven Inc., USA) with image analysis software (ImageJ, ver. 1.440, National Institute of Health, USA). Lobsters were weighed $(\mathrm{M} \pm 0.00001 \mathrm{~g})$ with an analytical scale [Mettler Toledo, AT261]. When mass couldn't be measured, it was estimated from CL measurements using the following length-mass relationship:

$$
\mathrm{M}=\alpha \mathrm{CL}^{\beta}
$$

Where $\alpha$ and $\beta$ are the elevation and steepness of the curve. Coefficients $\alpha\left(\exp ^{-7.56}, t=99.98\right.$, $p<0.0001)$ and $\beta(2.94, t=452.45, p<0.0001)$ were estimated by a nonlinear regression applied to $\mathrm{CL}$ and $\mathrm{M}$ measurements made on a wide range (2 to $8 \mathrm{~mm} \mathrm{CL}$ ) of 1600 lobsters between 2008 and 2011.

\subsection{Calculations and Data Analysis}

The OXY-4 collected oxygen partial pressure values $(\mathrm{kPa})$ that were converted using an oxygen solubility table $\left(\mathrm{mg} \cdot \mathrm{L}^{-1}\right)$, adjusted for temperature and salinity, to $\mathrm{mg} \mathrm{O}_{2}$ per unit of time based on the equation suggested by Benson and Krause (1980, 1984). Oxygen consumption $\left(\mathrm{MO}_{2}=\mathrm{mg} \mathrm{O} \mathrm{O}_{2} \cdot \mathrm{h}^{-1}\right)$ was calculated using the equation suggested by Steffensen (1989), later re-parameterized by Schurmann and Steffensen (1997). Background respiration was calculated by establishing a linear regression between respiration in empty chambers at the beginning and at the end of each session and then subtracted the overall oxygen consumption in each chamber. An empty chamber was used to establish the general trend of 
respiration without an animal during a complete session and to correct previously predicted values of blank in each chamber. SMR and AMR were calculated with the 0.10 (Daoud et al., 2007; Dorcas et al., 2004) and 0.99 (Schurmann \& Steffensen, 1997) quantiles, respectively. To account for variation of oxygen consumption due to size differences (wet mass range from 0.06 to $0.15 \mathrm{~g}$ ), standardized $\mathrm{SMR}_{0.1 \mathrm{~g}}$ and $\mathrm{AMR}_{0.1 \mathrm{~g}}$ to a $0.1 \mathrm{~g}$ juvenile lobster using 0.61 as the mass exponent (Logan \& Epifanio, 1978) were calculated based on the equations of Clarke and Johnston (Clarke \& Johnston, 1999).

The intermolt period (IP) represented the duration in days between two successive molts. The relative molt increment (MI) and specific growth rates (SGR) were calculated as previously done on shrimp (Daoud et al., 2010)

Mean values of metabolic rates and growth were compared between the two treatments by two-sample bilateral permutated t-tests (999 permutations) (Sokal \& Rohlf, 1995). Graphical examinations of the data and Brown-Forsythe tests (Brown \& Forsythe, 1974) were used to examine homogeneity of variances. Survival was compared between treatments with a Pearson's Chi-squared test applied to a two-by-two contingency table with Monte Carlo simulated $p$-value (based on 99999 replicates). All calculations and statistics were carried out with R 2.14.0 (R Development Core Team 2011).

All values of surface areas of histological section of the hepatopancreatic tubule were presented as means \pm standard error of the mean and statistical differences present at $5 \%$ level are considered significant (Zar, 1996). The values were checked for normality using the Shapiro-Wilk test. Statistical comparisons between the distributions of variables that do not show a normal distribution are made using Mann-Whitney test (Zar, 1996). SPSS 18 was used for these statistical analyses.

\section{Results}

\subsection{Metabolic Rates}

Lobsters were between 6 to 18 days post-molt, with a CL around $6 \mathrm{~mm}$ and a wet mass of $0.11 \mathrm{~g}$ (Table 2). A total of 10 metabolic sessions were conducted but 2 sessions were rejected from analysis due to technical problems (flushing pump breakdown and temperature instability in tank at the beginning). All lobsters survived the $96 \mathrm{~h}$ endosulfan exposure in 2010. For determination of metabolic rate, only 7 control and 8 exposed lobsters (group B) were used as lobsters that molted in the chambers were removed from analysis.

The initial size of lobsters between the two groups was similar. All the juveniles could swim for about $40 \mathrm{~min}$ before being exhausted. When lobsters were trying to rest and recover they had to be stimulated with a small jet of water without being stressed, i.e., avoiding tail-flicks. The location of the exercise beaker ensured minimum transportation time before measuring oxygen consumption rates (less than $5 \mathrm{~min}$ ). Mean $\mathrm{AMR}_{0.1 \mathrm{~g}}$ was 0.45 and $0.39 \mathrm{mg} \mathrm{O} \mathrm{O}_{2} \cdot \mathrm{h}^{-1} \cdot \mathrm{g}^{-1}$ while mean $\mathrm{SMR}_{0.1 \mathrm{~g}}$ was 0.07 and $0.09 \mathrm{mg} \mathrm{O} \cdot \mathrm{h}^{-1} \cdot \mathrm{g}^{-1}$ for control and exposed juveniles, respectively (Table 2). The difference between control and exposed lobsters for both $\mathrm{SMR}_{0.1 \mathrm{~g}}$ and $\mathrm{AMR}_{0.1 \mathrm{~g}}$ was not significant $(p>0.05)$. However, a significantly reduced MS in juvenile lobster exposed to endosulfan compared to the control group $\left(t_{2,13}=-2.96, p=0.011\right.$; Figure 1$)$ 
was observed. MS of control juveniles ranged from 0.36 to $0.41 \mathrm{mg} \mathrm{O} \cdot \mathrm{h}^{-1} \cdot \mathrm{g}^{-1}$ whereas MS of exposed juveniles ranged from 0.25 to $0.33 \mathrm{mg} \mathrm{O}{ }_{2} \cdot \mathrm{h}^{-1} \cdot \mathrm{g}^{-1}$.

Table 2. Size and metabolic rates for juvenile American lobsters in the 2010 experiment

\begin{tabular}{lll}
\hline & Control & Exposed \\
\hline $\mathrm{CL}$ & $6.17 \pm 0.43$ & $6.07 \pm 0.32$ \\
$\mathrm{M}$ & $0.1141 \pm 0.0170$ & $0.1030 \pm 0.0158$ \\
Swim & $2426 \pm 315$ & $2674 \pm 490$ \\
$\mathrm{SMR}_{\mathrm{g}}$ & $0.0780 \pm 0.0144$ & $0.0991 \pm 0.0224$ \\
$\mathrm{AMR}_{\mathrm{g}}$ & $0.4368 \pm 0.0245$ & $0.3965 \pm 0.0256$ \\
$\mathrm{SMR}_{0.1 \mathrm{~g}}$ & $0.0835 \pm 0.0179$ & $0.0941 \pm 0.0170$ \\
$\mathrm{AMR}_{0.1 \mathrm{~g}}$ & $0.4497 \pm 0.0323$ & $0.3859 \pm 0.0229$ \\
\hline
\end{tabular}

Notes: Cephalohorax length (CL in $\mathrm{mm}$ ), wet mass ( $\mathrm{M}$ in $\mathrm{g}$ ), swimming duration (Swim in seconds), adjusted to a $0.1 \mathrm{~g}$ animal standard $\left(\mathrm{SMR}_{0.1 \mathrm{~g}}\right)$ and active $\left(\mathrm{AMR}_{0.1 \mathrm{~g}}\right)$ metabolic rates $\left(\mathrm{mgO}_{2} \cdot \mathrm{h}^{-1} \cdot \mathrm{g}^{-1}\right)$ for juvenile lobsters (Homarus americanus) exposed to formulated endosulfan $\left(0.1 \mu \mathrm{g} \cdot \mathrm{L}^{-1}\right)$ for $96 \mathrm{~h}(\mathrm{n}=8)$ and control $(\mathrm{n}=7)$ animals. Specific standard $\left(\mathrm{SMR}_{\mathrm{g}}\right)$ and active $\left(\mathrm{AMR}_{\mathrm{g}}\right)$ metabolic rates are indicated to facilitate comparison with metabolic values present in the literature. Mean and standard error are presented. No significant difference was observed between treatments for all variables ( $t$-test permutation, $p<0.05$ ).

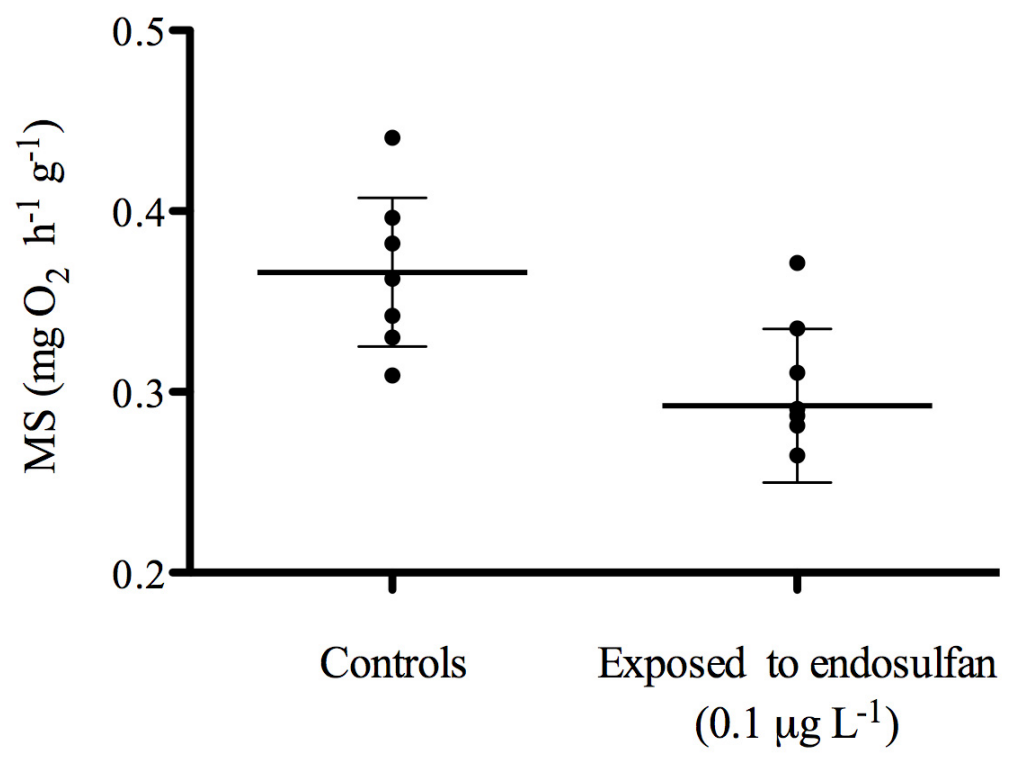

Figure 1. Metabolic scope (MS, aka aerobic scope) for juvenile lobsters (Homarus americanus) exposed to formulated endosulfan $\left(0.1 \mu \mathrm{g} \cdot \mathrm{L}^{-1}\right)$ for $96 \mathrm{~h}(\mathrm{n}=8)$ and control animals $(n=7)$

Notes: Mean and 95\% confidence interval are presented. A significant difference was detected between control and exposed animals ( $t$-test permutation, $p<0.05)$. 


\section{$\triangle 1$ Macrothink}

\subsection{Histology of the Hepatopancreas}

The hepatopancreas of control juvenile lobster (groups A1 and A2) was composed of a single layer of epithelial cells found in the lining of the tubules showing three principle types of cells: B-, F-, and R-cells (Figure 2). The hepatopancreatic tubules rest on a basal lamina and microvillus border the wide lumen (Figure 2). B-cells contain a large vacuole compressing the basal nucleus. F-cells stained deeply blue (i.e., indicative of a basophilic condition) with a prominent nucleus located in the central part of the cells (Figure 2). R-cells are also basophilic and possess a basally located nucleus and the cytoplasm with large amounts of lipid droplets (Figure 2).

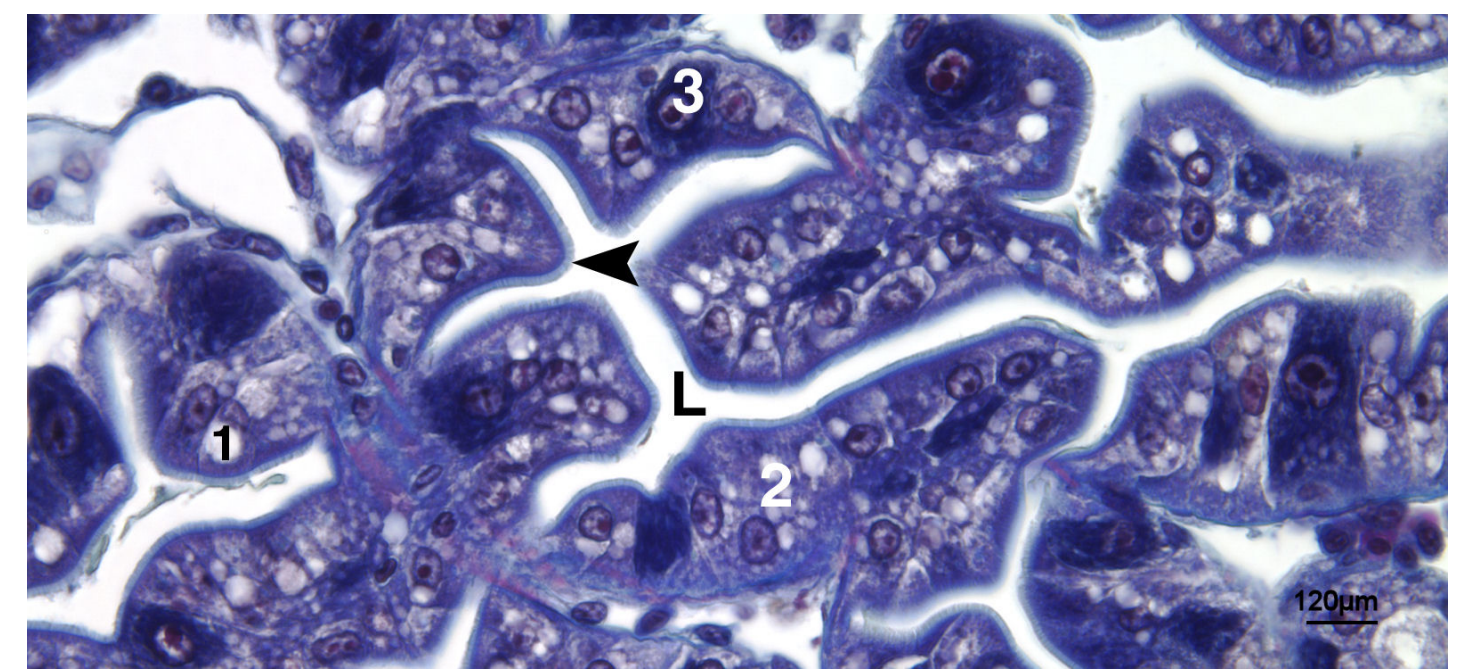

Figure 2. Light micrograph of cross sections of hepatopancreatic tubules of control juvenile lobsters (Homarus americanus) (4 to $8 \mathrm{~mm}$ of cephalothorax length) showing a lumen (L), microvillus (black arrowhead), B-cells (1), F-cells (2), and R-cells (3)

Note: The cytoplasm of all cells is basophilic.

Lobsters exposed to formulated endosulfan $\left(0.1 \mu \mathrm{g} \cdot \mathrm{L}^{-1}\right)$ for $96 \mathrm{~h}$ had altered hepatopancreas cells based on a series of observations (Figure 3). First, F-cell nuclei were increased in size (hypertrophy), and both F- and R-cells had lost their basophilic character (Figure 3A). Secondly, a higher number of vacuoles were observed in the R-cells and the lumen of the hepatopancreatic tubules appeared collapsed (Figure 3B) compared to a wide lumen observed in control animals (Figure 2). Thirdly, B-cells of the exposed lobsters appeared to be losing their shape and had numerous large vacuoles containing brown granules (Figure 3C). Finally, the basal membrane was detached from the epithelium of the hepatopancreatic tubules in exposed animals (Figure 3D). The same overall observations were found in the 2011 experiment (group D). 

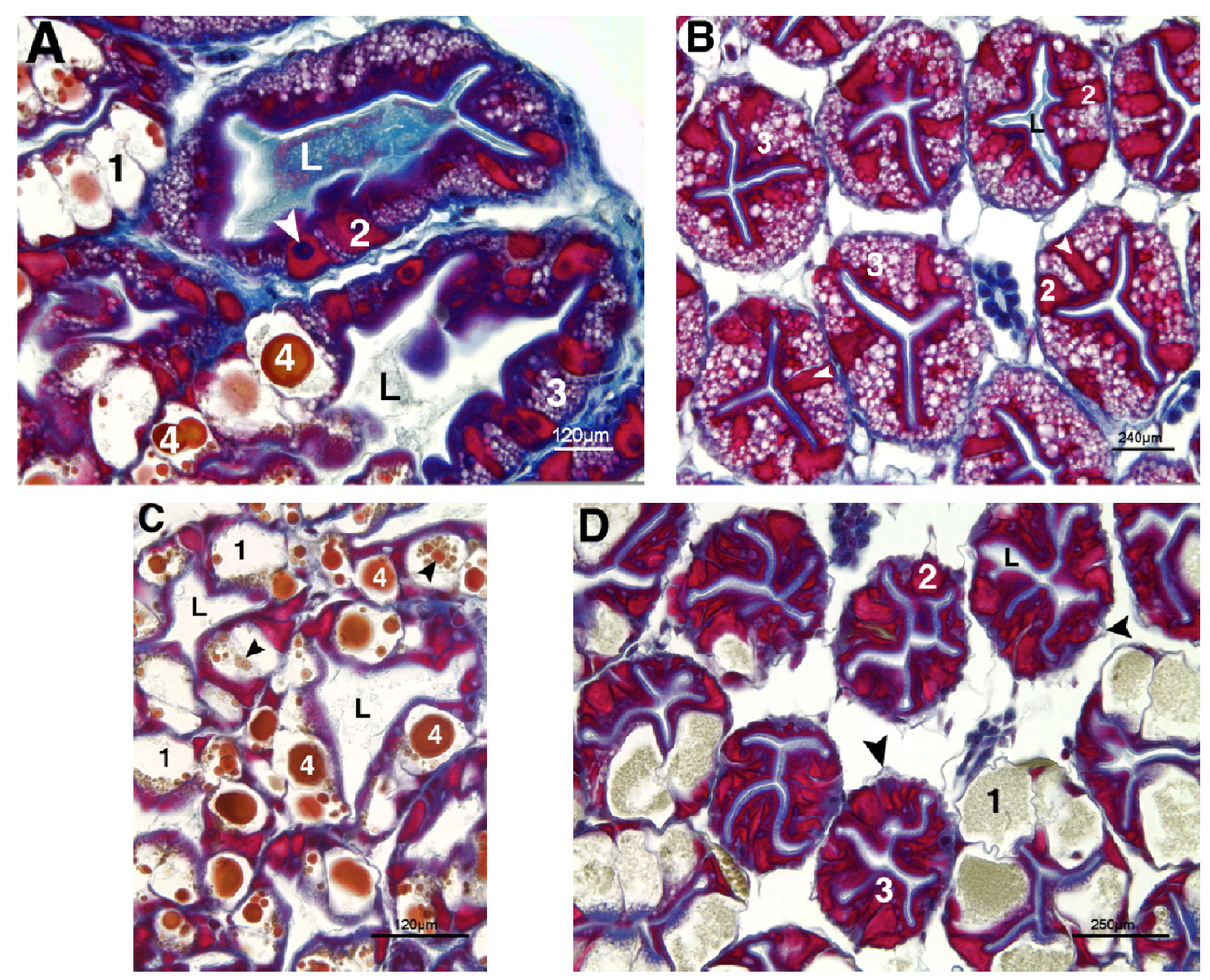

Figure 3. Light micrograph of cross sections of hepatopancreatic tubules of juvenile lobsters

(Homarus americanus) (4 to $8 \mathrm{~mm}$ of cephalothorax length) exposed to formulated endosulfan $\left(0.1 \mu \mathrm{g} \cdot \mathrm{L}^{-1}\right)$ for $96 \mathrm{~h}$

Notes: (A) F-cells are losing their basophilic character and hypertrophy of the nucleus (white arrowhead). Brown granules are observed in large vacuoles within B-cells. (B) R-cells show numerous vacuoles and their nuclei are smaller, condensed and have migrated to the apical part of cells. F-cells are already autolysis (white arrowhead). (C) B-cells have lost their regular shape and structure, and have increased in size with large vacuole containing brown granules of various sizes (black arrowhead). (D) Separation of basal lamina (black arrowhead) from necrotic cells of hepatopancreatic tubules. The picture shows a lumen (L), B-cells (1), F-cells (2), R-cells (3), and granules (4).

Overall surface area ratio of the R-, B-, F-cells and the lumen were not significantly different after exposure (group A1). However, the difference between surface area ratios of the B- and $\mathrm{R}$-cells in the corresponding surface area of the hepatopancreatic tubule for control and exposed lobsters after metabolic measurements (group A2) was significantly different ( $p=0.04$ and $p=0.004$. respectively) (Table 3 ). There was no significant difference between control and exposed lobsters in terms of surface area ratios of F-cells and their lumen in the corresponding surface area of the hepatopancreatic tubules. The B-cells surface area in the corresponding surface area of the hepatopancreatic tubules of control lobsters seems to be 


\section{Ml Macrothink}

Aquatic Science and Technology

ISSN 2168-9148

2014, Vol. 2, No. 2

significantly bigger than that of exposed lobsters $(p=0.04)$. Conversely, R-cells surface area of exposed lobsters were significantly bigger than those of control animals $(p=0.004)$ (Table $3)$.

Table 3. Quantitative histology for control and exposed juvenile American lobsters

\begin{tabular}{llll}
\hline & Median & Range & IQR \\
\hline Control Lumen / Tubule & 0.10 & 0.46 & 0.09 \\
Exposed Lumen / Tubule & 0.08 & 0.42 & 0.10 \\
Control B-cells / Tubule & 0.44 & 0.71 & 0.33 \\
Exposed B-cells / Tubule & 0.27 & 0.78 & 0.57 \\
Control F-cells / Tubule & 0.08 & 0.28 & 0.07 \\
Exposed F-cells / Tubule & 0.08 & 0.41 & 0.09 \\
Control R-cells / Tubule & 0.30 & 0.86 & 0.23 \\
Exposed R-cells / Tubule & 0.45 & 0.75 & 0.33 \\
\hline
\end{tabular}

Notes: The ratios of surface area measurements of lumen, R-, B- and F-cells to hepatopancreatic tubule for juvenile lobsters (Homarus americanus) exposed to formulated endosulfan $\left(0.1 \mu \mathrm{g} \cdot \mathrm{L}^{-1}\right)$ for $96 \mathrm{~h}$ and control animals in 2010. Median, range (representing minimum and maximum values), and interquartile range (IQR) are presented.

Histology of the hepatopancreas for post-molt exposed lobsters revealed that, although exposed to formulated endosulfan with the consequences mentioned above, cells of the digestive gland recovered (Figure 4) to a condition similar to non-exposed animals (Figure 2) after 2 to 4 days post-molt.

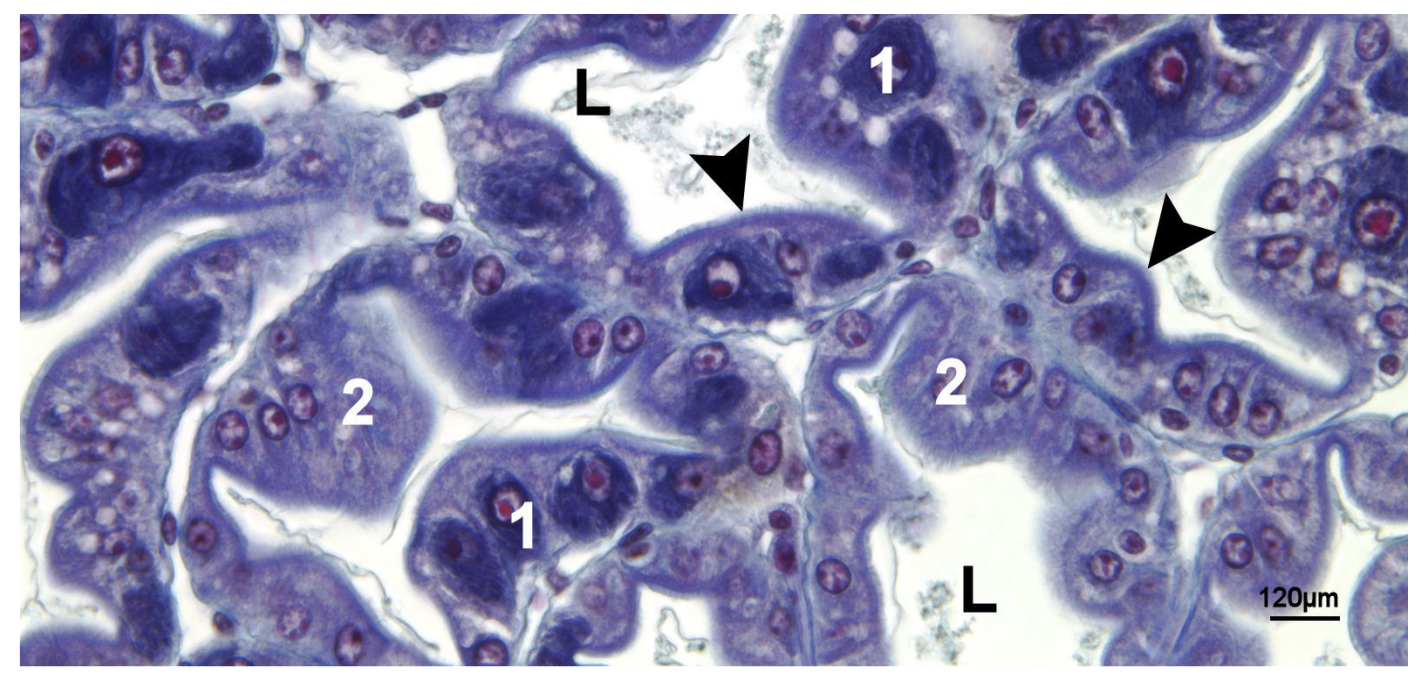

Figure 4. Light micrograph of cross sections of hepatopancreatic tubules of post-molt juvenile lobsters (Homarus americanus) that were exposed to formulated endosulfan $(0.1$ $\mu \mathrm{g} \cdot \mathrm{L}^{-1}$ ) for $96 \mathrm{~h}$ pre-molt

Notes: The B-, F- and R-cells are restored to a condition similar to control lobsters (see Fig. 2). The picture shows the lumen (L), F-cells (1), R-cells (2), and microvillus (black arrowhead). 


\subsection{Growth}

As observed in 2010, all lobsters survived the 96h endosulfan exposure in 2011 (group C). However, from the initial juvenile lobsters (25 control: 25 exposed), 1 control (4\%) and 5 exposed (25\%) animals died between 13 and 22 days post-molt. Mortality however was not significantly different between control and exposed groups $\left(\chi^{2}=3.80, p=0.08\right)$.

Table 4. Size and growth for juvenile American lobsters in the 2011 experiment

\begin{tabular}{lll}
\hline & Control & Exposed \\
\hline $\mathrm{CL}_{\mathrm{i}}(\mathrm{mm})$ & $4.72 \pm 0.10(21)$ & $4.98 \pm 0.13(18)$ \\
$\mathrm{CL}_{\mathrm{f}}(\mathrm{mm})$ & $5.48 \pm 0.10(22)$ & $5.83 \pm 0.18(15)$ \\
$\mathrm{MI}(\%)$ & $16.14 \pm 0.83(12)$ & $17.00 \pm 1.52(7)$ \\
$\mathrm{IP}($ days $)$ & $15.83 \pm 1.11(14)$ & $17.29 \pm 1.44(9)$ \\
\hline
\end{tabular}

Notes: Initial $\left(\mathrm{CL}_{\mathrm{i}}\right)$ and final $\left(\mathrm{CL}_{\mathrm{f}}\right)$ cephalothorax length, molt increment (MI) and intermolt period (IP) for juvenile lobsters (Homarus americanus) exposed to formulated endosulfan $\left(0.1 \mu \mathrm{g} \cdot \mathrm{L}^{-1}\right)$ for $96 \mathrm{~h}$ and control animals. Mean and standard error are presented. Total number of lobsters (n) in brackets. No significant difference was observed between treatments for all variables ( $t$-test permutation, $p<0.05)$.

The average $\mathrm{CL}_{\mathrm{i}}$ was 4.72 and $4.98 \mathrm{~mm}$ for control and exposed groups, respectively, with no significant difference ( $p=0.59$; Table 4 ). Molt increment (MI) ranged from $14.31 \%$ to $17.97 \%$ for the control group and from $13.28 \%$ to $20.71 \%$ for exposed lobsters. Mean MI (Table 4) was not significantly different $\left(t_{2,17}=-0.49, p=0.63\right)$. The duration between molts or intermoult period (IP) was not significantly different $\left(t_{2,22}=-0.25, p=0.84\right)$ (Table 4$)$. The SGR ranged from 0.0082 to 0.0119 for control and from 0.0074 to 0.0111 for exposed juvenile lobsters (Figure 5). There was no significant difference between these groups $\left(t_{2,17}=0.61, p=0.56\right)$.

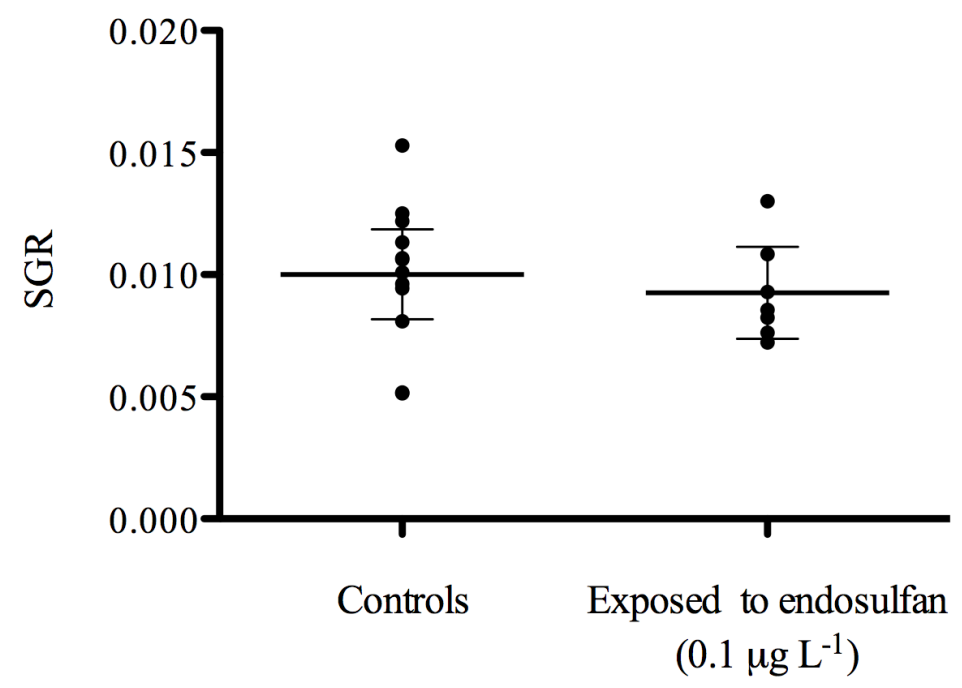

Figure 5. Specific growth rate (SGR) for juvenile lobsters (Homarus americanus) exposed to formulated endosulfan $\left(0.1 \mu \mathrm{g} \cdot \mathrm{L}^{-1}\right)$ for $96 \mathrm{~h}(\mathrm{n}=12)$ and control animals $(\mathrm{n}=7)$

Notes: Mean and 95\% confidence interval are presented. No significant difference was detected between control and exposed animals ( $t$-test permutation, $p<0.05$ ). 


\section{Discussion}

This study has enabled the measurement of MS, AMR and SMR of juvenile American lobsters for the first time using an intermittent-flow respirometry system. Most scientific studies assess the effects of pesticide on metabolic rates and oxygen consumption only, without using a more integrative approach such as MS that would be more representative of overall animal's energy surplus. Hence, contradictory results were found regarding the effect of pollutants with increased (Arnold et al., 2009; Montagna \& Collins, 2008; Rowe, 1998) or decreased (Dissanayake et al., 2008; Rao et al., 1981) oxygen consumption. Brown (2006) measured the effects of different diets on the oxygen consumption of lobsters ranging in size between 7-60 mm CL and found routine metabolic rates (RMR) between 0.097 and $0.39 \mathrm{mg}$ $\mathrm{O}_{2} \cdot \mathrm{h}^{-1} \cdot \mathrm{g}^{-1}$. Although Brown (2006) had used a Winkler titration approach to measure metabolic rates, with only one measurement session per individual, our values were quite similar. The difference in measurement techniques and approaches can account for the lower metabolic rates determined in our study. Brown (2006) had also found an allometric exponent of 0.76 , but since our technique is different we were more confident in using the allometric coefficient of 0.61 found by Logan and Epifanio (1978). This coefficient was estimated using RMR determinations and 4-18 mm CL lobsters, at $22{ }^{\circ} \mathrm{C}$. Logan and Epifanio (1978) measured oxygen consumption with a Gilson differential respirometer with a multi-session approach, which could be considered as an experimental setup comparable to ours. However, it was obvious that a precise allometric coefficient determination on the full size range for the American lobster is lacking. McLeese (1964) measured oxygen consumption on lobsters ranging from 0.9 to $308 \mathrm{~g}$, and found mean metabolic rates of $0.06 \mathrm{mg} \mathrm{O}_{2} \cdot \mathrm{h}^{-1} \cdot \mathrm{g}^{-1}$ at $15{ }^{\circ} \mathrm{C}$ for smaller lobsters, which are comparable to our results. Oxygen consumption for American lobster having a mean mass of $757 \mathrm{~g}$ at $5{ }^{\circ} \mathrm{C}$ was around $0.018 \mathrm{mg} \mathrm{O} \mathrm{O}_{2} \cdot \mathrm{h}^{-1} \cdot \mathrm{g}^{-1}$ (McLeese \& Watson, 1968). Differences in SMR between the studies could be accounted for the colder temperatures and the lack of allometric exponent correction used in studies conducted by McLeese (McLeese \& Watson, 1968; 1964). Logan and Epifanio (1978) also found high RMR rates and established metabolic-weight relationships. Assuming that a juvenile lobster contains approximately $86 \%$ moisture, we would have an average dry weight of around 15.96 mg per juvenile lobster for the controls. If the relationship determined by Logan and Epifanio (1978) for lobsters ranging from 4 to $18 \mathrm{~mm} \mathrm{CL}$, which were fed live Artemia and starved for $24 \mathrm{~h}$ at $22{ }^{\circ} \mathrm{C}$ before being used in their trials, was used in our calculations, we would find metabolic rates of around $0.1584 \mathrm{mg} \mathrm{O} \cdot \mathrm{h}^{-1} \cdot \mathrm{g}^{-1}$ wet weight. This represents a metabolic rate measure almost twice the level found in our study $\left(0.0780 \mathrm{mg} \mathrm{O} \mathrm{O}_{2} \cdot \mathrm{h}^{-1} \cdot \mathrm{g}^{-1}\right)$. It was clear that Logan and Epifanio (1978) measured RMR and not SMR and they worked at $22^{\circ} \mathrm{C}$ instead of $20^{\circ} \mathrm{C}$. It is well established that temperature is the most important extrinsic controlling factor influencing metabolic rates (Fry, 1971), as metabolic rates increase with temperature (Schmidt-Nielsen, 1990). In most studies found in the literature, techniques that were used allowed the measurement of RMR instead of SMR. RMR describes an organism that is feeding, growing, producing sexual products, spontaneous activity or any other activity that elevates the SMR (Lucas, 1993). SMR, reflecting the energy cost of self-maintenance, is considered to be linked to fitness, as it constitutes a central component of life-history budget allocations among the competing interests of self-maintenance, somatic and reproductive 
growth (Burton et al., 2011). For the giant freshwater prawns, Macrobrachium rosenbergii, SMR in juveniles was positively correlated to the social status of the shrimps (Brown et al., 2003). Burton et al. (2011) proposed that the relationship between MR and fitness may depend partly upon environmental conditions. Bioenergetic alterations were also reported for the freshwater catfish, Clarias batrachus, submitted to sublethal concentrations of endosulfan (Mishra \& Shukla, 1995).

In our study, AMR was 4 to 5 times greater than SMR. Parslow-Williams et al. (2002) measured AMR for adult Norway lobster (Nephrops norvegicus) using a closed respirometry system, exhausting lobsters by chasing them in a tank. The relationship between AMR of active lobsters and wet mass $(\mathrm{M})$ was $A M R=6.60 \mathrm{M}^{-0.25}$. If we use this relationship, predicted AMR for our experiment would have been 0.3635 and $0.3731 \mathrm{mg} \mathrm{O}_{2} \mathrm{~h}^{-1} \mathrm{~g}^{-1}$ for control and exposed lobster, respectively, which is similar to our findings. It is possible however that AMR estimated in our study could have been underestimated because of the technique used to exhaust lobsters. Houlihan et al. (1985) measured oxygen consumption of American lobsters from 9 to $46 \mathrm{~g}$ under various exercise levels. They found that within $5 \mathrm{~min}$ after the end of the exercise, lobsters tend to return to their previous resting metabolism. In our case, in order to place the animal in the metabolic chamber, there was a small delay (2-5 min) between the end of the exhaustion exercise and the beginning of the measurement period. It would have been more accurate to measure AMR, although more difficult (for small crustacean), during the exercise period within the metabolic chambers. Hamilton and Houlihan (1992) measured respiration of the European shore crab Carcinus maenas with a treadmill system. This approach could be difficult, considering the size of animals used in our study. It was shown that metabolic rates were increased by 3.4 times during constant exercise and that $\mathrm{MO}_{2}$ decreased drastically 6 min after the end of exercise period. AMR can also be measured by an enzymatic approach that measures the electron transport capacity within the cell (Packard \& Williams, 1981). However, the Electron Transport System Activity (ETSA) method doesn't take into account the whole energetic demand of the organism. Chabot and Ouellet (2005) estimated that ETSA was around 3.7 to 5 times higher than RMR for the Northern shrimp, Pandalus borealis larval stages. Factorial aerobic scopes (AMR/SMR) in our study (5.6 and 4.3 for control and exposed animals, respectively) were comparable to measurements previously performed on American lobster (about 4 to 3) (Houlihan et al. 1985). However, methods used in previous studies are suspected of overestimating SMR and are considered to be closer to RMR, which could explain smaller factorial aerobic scopes, since RMR is higher than SMR.

Our experiments also looked at the effects of endosulfan exposure on growth parameters such as MI, IP and SGR. Our values of MI for control lobsters were within the range found for wild juveniles (16 and $23 \%$ in Gendron and Sainte-Marie (2006)). Also, environmental stressors can influence IP in crustaceans (Hartnoll, 1981, 1982), but in our study the overall SGR was not significantly influenced by endosulfan exposure. Molt is a very demanding energetic process and increased mortality during molt could or can be expected. In our study, survival rates were not significantly affected by exposure to endosulfan. It is obvious that the ad libitum access to food could help compensate for potential energetic stresses. 
Nevertheless, a significantly smaller MS was observed for endosulfan-exposed juveniles compared to controls. Furthermore, this lower MS was not linked to a decrease in growth suggesting that some compensatory mechanisms could be in place for stressful effects of contaminants on physiological processes. Hence, it seems that lobsters might adjust their metabolism to contaminant stress by maintaining a positive energy balance. Growth measurements from one molt cycle could be insufficient for verifying possible effects of sub-lethal concentrations of endosulfan on growth. Gene expression analysis could provide interesting insights in order to detect molecular dysfunctions related to some hormones related to growth or metabolic functions. It was shown that a 14 days exposure to endosulfan changes significantly the expression of genes related to molt processes such as FTZ-F1 and FAO-MeT (Bauer et al., 2013). Genes involved in $\mathrm{Ca}^{2+}$ regulation were also down regulated that could impair exoskeleton development (Bauer et al., 2013). Besides these impacts of endosulfan on developmental genes, it was also shown that larvae exposed to endosulfan had a depressed immune system and were unable to mount a protective response to oxidative stress. Our experimental set-up didn't allow us to detect changes at this level of integrations but could explain the drop in MS for exposed lobsters.

The histology of lobster hepatopancreas corroborates our results of a reduced metabolic rate for the exposed group based on B-cells and R-cells measurements. Results showed that the total area of B-cells per tubule for the exposed group was smaller compared to the control group. It seems that the B-cells had less undigested substances absorbed via pinocytosis (e.g., toxic mineral elements, digestive enzymes, undigested particles) (Brunet et al., 1994) for exposed animals. Conversely, the total area of the R-cells per tubule was larger for the exposed group and an increase in the number of the R-cells was also observed. Similarly, Bhavan and Geraldine (2000) had already reported that the number of the R-cells per tubule is increased following an endosulfan exposure in the freshwater Monsoon river prawn, Macrobrachium malcolmsonii. Furthermore, an expansion of the R-cells could also be observed during starvation because they become a source of nutrients for the animal. A few studies showed that starved crustaceans had empty lipid vacuoles and reduced lipid content in their digestive gland suggesting that the larger area of these cells is indicative of excessive intracellular digestion and/or elimination of waste products such as digestive enzymes and undigested particles (Barker \& Gibson, 1977; Brunet et al., 1994). There is also evidence from other crustacean species that hepatopancreatic histopathology is linked to endosulfan exposure. Bhavan and Geraldine (2000) showed that the hepatopancreas cell ultrastructure of M. malcolmsonii, was altered after exposure to endosulfan. While Yadwad (1992) showed a decrease in lipid synthesis and depletion of lipid reserves in the hepatopancreas of endosulfan exposed field crabs, Paratelphusa hydrodromus. This lipid reserve depletion could be explained by an increased energy demand required for the crabs' movement away from pollutant contamination. For juvenile lobsters, the R-cells alteration could also be a consequence of altered lipogenic capacity of the hepatopancreas. In the current study we observed that the effect induced by sublethal endosulfan exposure on the hepatopancreas cellular architecture of juvenile lobster was transient as post-molt exposed lobsters' hepatopancreas were similar to controls. This observation supports the idea that the use of multiple physiological measurement approaches in order to better understand the dynamics of 
intermediary metabolism may be important.

There are various types of physiological response measurements that could be looked at in future studies of this nature. Most eco-physiologists use biochemical approaches to understand relationships between organisms and their environment (Dahlhoff, 2004). Metabolic enzymes, heat shock proteins, RNA/DNA ratios (Galindo et al., 1996), cellular respiration rates (Verslycke et al., 2004) and immunocompetency (Dissanayake et al., 2008) were often used to understand contaminant stress induced in marine organisms. Biochemical and physiological alterations by pesticides in penaeid shrimps have been widely studied (Dorts et al., 2009; Galindo et al., 1996; Suryavanshi et al., 2009). An increase in glycogenolysis with increasing concentrations of endosulfan in the freshwater field crab, Barytelphusa guerini, suggested an unbalanced energy metabolism, although more enzymatic measurements had to be done to understand the actual processes behind these changes (Reddy et al., 1995; Reddy et al., 1991). Oxidative stress status and heat shock protein levels in the black tiger shrimp, Panaeus monodon, exposed to 0.1 and $1 \mu \mathrm{g} \cdot \mathrm{L}^{-1}$ of endosulfan where highly increased in the muscle (Dorts et al., 2009). Proximate composition of gills, hepatopancreas and muscle of the penaeid shrimp, Matapenaeus monoceros, was affected by sublethal concentrations of endosulfan $\left(0.04\right.$ and $\left.0.06 \mu \mathrm{g} \cdot \mathrm{L}^{-1}\right)$ indicating a reduction in nutritional status of exposed shrimps (Suryavanshi et al., 2009). Individually, all of these indices have limitations in terms of their capacity to explain the global effects of contaminant exposure on the organism, since information on the different pathways involved are not well known. Studies that explore global changes in gene expression may afford an opportunity to assimilate information from multiple systems and help refine future metabolic studies during pesticide exposure (Bauer et al., 2013).

In this study, resting metabolism, growth and survival rates were not significantly affected by a sublethal stress, however this did not translate into a normal overall metabolic scope for the exposed animals. According to Biro (2010), a decreased metabolic scope such as observed in this study $(-25 \%)$ would probably translate into behavioral differences that could have severe consequences on survival in natural environments (Reebs et al., 2011). Thus, future studies assessing metabolic changes in lobsters should incorporate behavioral metrics, in order to better extrapolate pesticide effects to outcomes in natural settings. In the context of coastal waters, Hartwell (2011) suggested a link between several years of lower Chesapeake Bay blue crab (Callinetes sapidus) harvests and higher toxic units of insecticides application, particularly the contribution from pyrethroid pesticides. Another example of a potential link between a crustacean fishery collapse and pesticides was explored for the North Sea brown shrimp (Crangon crangon) and organotin compounds found in local sediments (Verhaegen et $a l ., 2012$ ). The total amount of pesticide (including organochlorines) used in Prince Edward Island (PEI, Canada), which borders on the Northumberland Strait, is in the same range as in Chesapeake Bay (Hartwell, 2011; PEI, 2011). These plausible relationships between harvested crustaceans and pesticides may be applicable to lobster.

\section{Conclusion}

This study provided the first values of metabolic rates and metabolic scope on American 
lobster's early stages and adds to the growing body of literature supporting the idea that sublethal contaminant levels can affect the ability of marine organisms to survive and thrive in the wild. Approaches combining direct and indirect measurements of animal condition, to assess survival of contaminant-exposed organisms in their environment seems to be a cautious approach. An integrative physiological endpoint, such as MS, if combined with behavioral measurements, and gene expression studies could provide relevant measurements of potential life-history responses patterns of American lobster exposed to contaminants. Although this study was not designed to link natural lobster recruitment problems (e.g. Northumberland Strait) to endosulfan exposure, it does suggest that sublethal concentrations could have deleterious effects on juvenile lobsters in the wild. Further investigations are warranted and should look at determining if relevant concentration levels of this contaminant are present in the lobster's distribution range, especially in areas of juvenile settlement. This step would be necessary in order to better assess the risk that endosulfan poses to lobster juvenile recruitment and population structure.

\section{Acknowledgement}

This study was funded through Fisheries and Oceans Canada (Fisheries Science Collaborative Program and National Pesticide Research Fund), Environment Canada and the Atlantic Lobster Sustainability Foundation. Lobster larvae were provided by Homarus Inc. and the Coastal Zones Research Institute (Shippagan, NB, Canada) and were transported live by Jacqueline Arsenault (DFO). We are very grateful to Fabiola Akaishi, Charles Hopper and Karen Robertson for their technical assistance during the experiments at the Environment Canada Atlantic Laboratory for Environmental Testing facility. We are also indebted to Dr. Spencer Greenwood for his support, and particularly for providing his insights on this paper and his willingness to share thoughts and ideas. All experiments were conducted in compliance with the current guidelines of the Canadian Council on Animal Care.

\section{References}

Arnold, K. E., Wells, C., \& Spicer, J. I. (2009). Effect of an insect juvenile hormone analogue, Fenoxycarb on development and oxygen uptake by larval lobsters Homarus gammarus (L.). Comparative Biochemistry and Physiology Part C: Toxicology and Pharmacology, 149(3), 393-396. http://dx.doi.org/10.1016/j.cbpc.2008.09.007

Baird, D. J., Barber, I., \& Calow, P. (1990). Clonal variation in general responses of Daphnia magna Straus to toxic Stress. I. Chronic life-history effects. Functional Ecology, 4(3), 399-407. http://dx.doi.org/10.2307/2389602

Barker, P. L., \& Gibson, R. (1977). Observations on the feeding mechanism, structure of the gut, and digestive physiology of the european lobster Homarus gammarus (L.) (Decapoda: Nephropidae). Journal of Experimental Marine Biology and Ecology, 26(3), 297-324. http://dx.doi.org/10.1016/0022-0981(77)90089-2

Bauer, M., Greenwood, S. J., Clark, K. F., Jackman, P., \& Fairchild, W. (2013). Analysis of gene expression in Homarus americanus larvae exposed to sublethal concentrations of endosulfan during metamorphosis. Comparative Biochemistry and Physiology Part D: 
Genomics and Proteomics, 8(4), 300-308. http://dx.doi.org/10.1016/j.cbd.2013.07.002

Benson, B. B., \& Krause, D. J. (1980). The concentration and isotopic fractionation of gases dissolved in freshwater in equilibrium with the atmosphere. 1. Oxygen. Limnology and Oceanography, 25(4), 662-671. http://dx.doi.org/10.4319/1o.1980.25.4.0662

Benson, B. B., \& Krause, D. J. (1984). The concentration and isotopic fractionation of oxygen dissolved in freshwater and seawater in equilibrium with the atmosphere. Limnology and Oceanography, 29(3), 620-632. http://dx.doi.org/10.4319/1o.1984.29.3.0620

Berillis, P., Simon, C., Mente, E., Sofos, F., \& Karapanagiotidis, I. T. (2013). A novel image processing method to determine the nutritional condition of lobsters. Micron, 45(0), 140-144. http://dx.doi.org/10.1016/j.micron.2012.10.014

Beyger, L., Orrego, R., Guchardi, J., \& Holdway, D. (2012). The acute and chronic effects of endosulfan pulse-exposure on Jordanella floridae (Florida flagfish) over one complete life-cycle. Ecotoxicology and Environmental Safety, 76(0), 71-78. http://dx.doi.org/10.1016/j.ecoenv.2011.09.015

Bhavan, P. S., \& Geraldine, P. (2000). Histopathology of the hepatopancreas and gills of the prawn Macrobrachium malcolmsonii exposed to endosulfan. Aquatic Toxicology, 50(4), 331-339. http://dx.doi.org/10.1016/S0166-445X(00)00096-5

Biro, P. A., \& Stamps, J. A. (2010). Do consistent individual differences in metabolic rate promote consistent individual differences in behavior? Trends in Ecology \& Evolution, 25(11), 653-659. http://dx.doi.org/10.1016/j.tree.2010.08.003

Brown, A. C. (2006). Effect of natural and laboratory diet on O: $\mathrm{N}$ ratio in juvenile lobsters (Homarus americanus). Comparative Biochemistry and Physiology Part A: Molecular \& Integrative Physiology, 144(1), 93-97. http://dx.doi.org/10.1016/j.cbpa.2006.02.008

Brown, J. H., Ross, B., McCauleya, S., Dancea, S., Taylor, A. C., \& Huntingford, F. A. (2003). Resting metabolic rate and social status in juvenile giant freshwater prawns, Macrobrachium rosenbergii. Marine and Freshwater Behaviour and Physiology, 36(1), 31. http://dx.doi.org/10.1080/1023624021000054307

Brown, M. B., \& Forsythe, A. B. (1974). Robust tests for the equality of variances. Journal of the American Statistical Association, 69(346), 364-367. http://dx.doi.org/10.1080/01621459.1974.10482955

Brunet, M., Arneaud, J., \& Mazza, J. (1994). Gut structure and digestive cellular processes in marine Crustacea. Oceanography and marine biology: an annual review, 32, 335-367.

Burridge, L. E., Haya, K., \& Waddy, S. L. (2008). The effect of repeated exposure to azamethiphos on survival and spawning in the American lobster (Homarus americanus). Ecotoxicology and Environmental Safety, 69(3), 411-415. http://dx.doi.org/10.1016/j.ecoenv.2007.05.001

Burton, T., Killen, S. S., Armstrong, J. D., \& Metcalfe, N. B. (2011). What causes 
intraspecific variations in resting metabolic rate and what are its ecological consequences? Proceedings of the Royal Society of London, Series B: Biological Sciences, 278(1724), 3465-3473. http://dx.doi.org/10.1098/rspb.2011.1778

CCME. (2010). Canadian water quality guidelines for the protection of aquatic life: Endosulfan. Winnipeg, MB.

Chabot, D., \& Ouellet, P. (2005). Rearing Pandalus borealis larvae in the laboratory II. Routine oxygen consumption, maximum oxygen consumption and metabolic scope at three temperatures. Marine biology, 147(4), 881-894. http://dx.doi.org/10.1007/s00227-005-1626-5

Clarke, A., \& Johnston, N. M. (1999). Scaling of metabolic rate with body mass and temperature in teleost fish. Journal of Animal Ecology, 68(5), 893-905. http://dx.doi.org/10.1046/j.1365-2656.1999.00337.x

Comeau, M., Hanson, J. M., Mallet, M., \& Savoie, F. (2004). Stock status of the American lobster, Homarus americanus, in the Lobster Fishing Area 25. Canadian Atlantic Fisheries Science Advisory Committee. Research Document 04/054, 75p.

Comeau, M., Hanson, J. M., Rondeau, A., Mallet, M., \& Chassé, J. (2008). Framework and assessment for American lobster, Homarus americanus, fisheries in the Southern Gulf of St. Lawrence: LFA 23, 24, 25, $26 A$ and 26B. Canadian Atlantic Fisheries Science Advisory Secretariat. Research Document 2008/054, 115p.

Dahlhoff, E. P. (2004). Biochemical indicators of stress and metabolism: applications for marine ecological studies. Annual Review of Physiology, 66(1), 183-207. http://dx.doi.org/10.1146/annurev.physiol.66.032102.114509

Daoud, D., Chabot, D., Audet, C., \& Lambert, Y. (2007). Temperature induced variation in oxygen consumption of juvenile and adult stages of the northern shrimp, Pandalus borealis. Journal of Experimental Marine Biology and Ecology, 347(1-2), 30-40. http://dx.doi.org/10.1016/j.jembe.2007.02.013

Daoud, D., Lambert, Y., Audet, C., \& Chabot, D. (2010). Size and temperature-dependent variations in intermolt duration and size increment at molt of Northern Shrimp, Pandalus borealis. Marine biology, 157, 2655-2666. http://dx.doi.org/10.1007/s00227-010-1526-1

De Guise, S., Maratea, J., Chang, E. S., \& Perkins, C. (2005). Resmehtrin immunotoxicity and endocrine disrupting effects in the American lobster (Homarus americanus) upon experimental exposure. Journal of Shellfish Research, 24(3), 781-786. http://dx.doi.org/10.2983/0730-8000(2005)24\%5B781:RIAEDE\%5D2.0.CO;2

DFO. (2010). Canadian marine ecosystem status and trends report. Canadian Science Advisory Secretariat. Research Document 2010/030, 38p.

Dissanayake, A., Galloway, T. S., \& Jones, M. B. (2008). Physiological responses of juvenile and adult shore crabs Carcinus maenas (Crustacea: Decapoda) to pyrene exposure. Marine Environmental Research, 66(4), 445-450. http://dx.doi.org/10.1016/j.marenvres.2008.07.006 
Dorcas, M. E., Hopkins, W. A., \& Roe, J. H. (2004). Effects of body mass and temperature on standard metabolic rate in the Eastern Diamondback rattlesnake (Crotalus adamanteus). Copeia, 2004(1), 145-151. http://dx.doi.org/10.1643/CP-03-074R1

Dorts, J., Silvestre, F., Tu, H. T., Tyberghein, A.-E. E., Phuong, N. T., \& Kestemont, P. (2009). Oxidative stress, protein carbonylation and heat shock proteins in the black tiger shrimp, Penaeus monodon, following exposure to endosulfan and deltamethrin. Environmental Toxicology and Pharmacology, 28(2), 302-310. http://dx.doi.org/10.1016/j.etap.2009.05.006

Ernst, W., Jackman, P., Doe, K., Page, F., Julien, G., MacKay, K., et al. (2001). Dispersion and toxicity to non-target aquatic organisms of pesticides used to treat sea lice on salmon in net pen enclosures. Marine Pollution Bulletin, 42(6), 432-443. http://dx.doi.org/10.1016/S0025-326X(00)00177-6

Fairchild, W. L., Doe, K. G., Jackman, P. M., Arsenault, J. T., Aubé, J. G. G., Losier, M., et al. (2010). Acute and chronic toxicity of two formulations of the pyrethroid pesticide deltamethrin to an amphipod, sand shrimp and lobster larvae. Canadian Technical Report of Fisheries and Aquatic Sciences, 2876.

Fry, F. E. J. (1971). The effect of environmental factors on the physiology of fish. In W. S. Hoar \& D. J. Randall (Eds.), Environmental relations and behavior (pp. 1-98). New York: Academic.

Gabe, M. (1968). Techniques histologiques (p.1113). Paris: Masson \& Cie.

Galindo, R. J., Medina, J. A., \& Villagrana, L. C. (1996). Physiological and biochemical changes in shrimp larvae (Penaeus vannamei) intoxicated with organochlorine pesticides. $\begin{array}{llll}\text { Marine } \quad \text { Pollution } & \text { Bulletin, } & 32(12), & \text { 872-875. }\end{array}$ http://dx.doi.org/10.1016/S0025-326X(96)00048-3

Gendron, L., \& Sainte-Marie, B. (2006). Growth of juvenile lobster Homarus americanus off the Magdalen Islands (Quebec, Canada) and projection of instar and age at commercial size. Marine Ecology Progress Series, 326, 221-233. http://dx.doi.org/10.3354/meps326221

Giambérini, L., \& Cajaraville, M. P. (2005). Lysosomal responses in the digestive gland of the freshwater mussel, Dreissena polymorpha, experimentally exposed to cadmium. Environmental Research, 98(2), 210-214. http://dx.doi.org/10.1016/j.envres.2004.11.003

Gormley, K., Teather, K., \& Guignion, D. (2005). Changes in salmonid communities associated with pesticide runoff events. Ecotoxicology, 14(7), 671-678. http://dx.doi.org/10.1007/s10646-005-0017-5

Hamilton, N. M., \& Houlihan, D. F. (1992). Respiratory and circulatory adjustments during aquatic treadmill exercise in the European shore crab Carcinus Maenas. Journal of Experimental Biology, 162, 37-54

Hartnoll, R. G. (1981). The control of size variation within instars of a crustacean. Journal of Experimental Marine Biology and Ecology, 53, 235-239. 
http://dx.doi.org/10.1016/0022-0981(81)90022-8

Hartnoll, R. G. (1982). Growth. In L. G. Abele (Ed.), The biology of Crustacea (Vol. 2, pp. 11-96). New York: Academic Press.

Hartwell, S. I. (2011). Chesapeake Bay watershed pesticide use declines but toxicity increases. Environmental Toxicology and Chemistry, 30(5), 1223-1231. http://dx.doi.org/10.1002/etc.491

Hellou, J., Leonard, J., Cook, A., Doe, K., Dunphy, K., Jackman, P., et al. (2009). Comparison of the partitioning of pesticides relative to the survival and behaviour of exposed amphipods. Ecotoxicology, 18(1), 27-33. http://dx.doi.org/10.1007/s10646-008-0253-6

Horst, M. N., Walker, A. N., Bush, P., Wilson, T., Chang, E. S., Miller, T., et al. (2007). Pesticide induced alterations in gene expression in the lobster, Homarus americanus. Comparative Biochemistry and Physiology Part D: Genomics Proteomics, 2(1), 44-52. http://dx.doi.org/10.1016/j.cbd.2006.11.004

Houlihan, D. F., Govind, C. K., \& El Haj, A. (1985). Energetics of swimming in Callinectes sapidus and walking in Homarus americanus. Comparative Biochemistry and Physiology Part A: Molecular and Integrative Physiology, 82(2), 267-279. http://dx.doi.org/10.1016/0300-9629(85)90853-9

Lakshminarayana, J. S. S., O’Neill, H. J., Jonnavithula, S. D., Leger, D. A., \& Milburn, P. H. (1992). Impact of atrazine-bearing agricultural tile drainage discharge on planktonic drift of a natural stream. Environmental Pollution, 76(3), 201-210. http://dx.doi.org/10.1016/0269-7491(92)90138-Z

Laufer, H., Baclaski, B., \& Koehn, U. (2012). Alkylphenols affect lobster (Homarus americanus) larval survival, molting and metamorphosis. Invertebrate Reproduction \& Development, 56(1), 66-71. http://dx.doi.org/10.1080/07924259.2011.588889

Logan, D. T., \& Epifanio, C. E. (1978). A laboratory energy balance for the larvae and juveniles of the American lobster Homarus americanus. Marine Biology, 47, 381-389. http://dx.doi.org/10.1007/BF00388930

Lombardi, J. V., Machado-Neto, J. G., Brossi-Garcia, A. L., Marques, H. L. A., \& Kubo, E. (2001). Acute toxicity of the pesticides endosulfan and ametryne to the freshwater prawn Macrobrachium rosenbergii De Man. Bulletin of Environmental Contamination and Toxicology, 67(5), 665-671. http://dx.doi.org/10.1007/s001280175

Lucas, A. (1993). Bioénergétique des animaux aquatiques (p.190). Paris (FRANCE): Masson.

Magel, C. R., Shields, J. D., \& Brill, R. W. (2009). Idiopathic lesions and visual deficits in the american lobster (Homarus americanus) from Long Island Sound, NY. Biological Bulletin, $217(1), 95-101$.

McLeese, D. W. (1964). Oxygen consumption of the lobster, Homarus americanus 
Milne-Edwards. Helgoland marine research, 10(1-4), 7-18.

McLeese, D., \& Watson, J. (1968). Oxygen consumption of the spider crab (Chionoecetes opilio) and the American lobster (Homarus americanus) at low temperature. Journal of the Fisheries Research Board of Canada, 25(8), 1729-1732. http://dx.doi.org/10.1139/f68-151

Mishra, R., \& Shukla, S. P. (1995). Effects of endosulfan on bioenergetic properties of skeletal muscle mitochondria from the freshwater catfish (Clarias batrachus). Comparative Biochemistry and Physiology Part C: Pharmacology(2), 153-161. http://dx.doi.org/10.1016/0742-8413(95)02007-1

Montagna, M. C., \& Collins, P. A. (2008). Oxygen consumption and ammonia excretion of the freshwater crab Trichodactylus borellianus exposed to chlorpyrifos and endosulfan insecticides. Pesticide Biochemistry and Physiology, 92(3), 150-155. http://dx.doi.org/10.1016/j.pestbp.2008.07.009

Packard, T. T., \& Williams, P. J. (1981). Rates of respiratory oxygen consumption and electron transport in surface seawater from the Northwest Atlantic. Oceanologica acta, 4(3), 351-358.

Parslow-Williams, P., Goodheir, C., Atkinson, R. J. A., \& Taylor, A. C. (2002). Feeding energetics of the Norway lobster, Nephrops norvegicus in the Firth of Clyde, Scotland. Ophelia, 56(2), 101-120.

PEI. (2011). 2010 state of the environment. Prince Edward Island: Department of environment, energy and forestry. $88 \mathrm{p}$.

Rao, D. M. R., Devi, A. P., \& Murty, A. S. (1981). Toxicity and metabolism of endosulfan and its effect on oxygen consumption and total nitrogen excretion of the fish Macrognathus aculeatum. Pesticide Biochemistry and Physiology, 15, 282-287.

Reddy, A. N., Venugopal, N. B. R. K., \& Reddy, S. L. N. (1991). Effect of endosulfan 35 EC on glycogen metabolism in the hemolymph and tissues of a freshwater field crab Barytelphusa guerini. Pesticide Biochemistry and Physiology, 40(2), 176-180. http://dx.doi.org/10.1016/0048-3575(91)90113-Z

Reddy, A. N., Venugopal, N. B., \& Reddy, S. L. (1995). Effect of endosulfan 35 EC on some biochemical changes in the tissues and haemolymph of a freshwater field crab, Barytelphusa guerini. Bulletin of Environmental Contamination and Toxicology, 55(1), 116-121. http://dx.doi.org/10.1007/BF00212397

Reebs, S. G., Jackman, P. M., Locke, A., \& Fairchild, W. L. (2011). Avoidance by sand shrimp, Crangon septemspinosa, of sandy patches covered by hydrated lime (calcium hydroxide) deposits. Canadian Technical Report of Fisheries and Aquatic Sciences, 2938.

Rowe, C. L. (1998). Elevated standard metabolic rate in a freshwater shrimp (Palaemonetes paludosus) exposed to trace element-rich coal combustion waste. Comparative Biochemistry and Physiology - Part A: Molecular and Integrative Physiology, 121(4), 299-304. http://dx.doi.org/10.1016/S1095-6433(98)10141-1 
Schmidt-Nielsen, K. (1990). Animal physiology: adaptation and environment (4th ed., p. 699). Cambridge, UK: Cambridge University Press.

Schurmann, H., \& Steffensen, J. F. (1997). Effects of temperature, hypoxia and activity on the metabolism of juvenile Atlantic cod. Journal of Fish Biology, 50(6), 1166-1180.

Sokal, R. R., \& Rohlf, F. J. (1995). Biometry-The principles and practice of statistics in biological research (3rd ed., p. 887). New York: Freeman and Co.

Steffensen, J. F. (1989). Some errors in respirometry of aquatic breathers: how to avoid and correct for them. Fish Physiology and Biochemistry, 6(1), 49-59. http://dx.doi.org/10.1007/BF02995809

Suryavanshi, U., Sreepada, R. A., Ansari, Z. A., Nigam, S., \& Badesab, S. (2009). A study on biochemical changes in the penaeid shrimp, Metapenaeus monoceros (Fabricius) following exposure to sublethal doses of organochlorine pesticide (endosulfan). Chemosphere, 77(11), 1540-1550. http://dx.doi.org/10.1016/j.chemosphere.2009.09.051

Tengberg, A., Hovdenes, J., Andersson, H. J., Brocandel, O., Diaz, R., Hebert, D., et al. (2006). Evaluation of a lifetime-based optode to measure oxygen in aquatic systems. Limnology and Oceanography: Methods, 4, 7-17. http://dx.doi.org/10.4319/lom.2006.4.7

Tuduri, L., Harner, T., Blanchard, P., Li, Y.-F.-F., Poissant, L., Waite, D. T., et al. (2006). A review of currently used pesticides (CUPs) in Canadian air and precipitation-Part 1: Lindane and endosulfans. Atmospheric Environment, 40(9), 1563-1578. http://dx.doi.org/10.1016/j.atmosenv.2005.11.034

Verhaegen, Y., Monteyne, E., Neudecker, T., Tulp, I., Smagghe, G., Cooreman, K., et al. (2012). Organotins in North Sea brown shrimp (Crangon crangon L.) after implementation of the $\quad$ TBT ban. Chemosphere, 86(10), 979-984. http://dx.doi.org/10.1016/j.chemosphere.2011.11.028

Verslycke, T., Roast, S. D., Widdows, J., Jones, M. B., \& Janssen, C. R. (2004). Cellular energy allocation and scope for growth in the estuarine mysid Neomysis integer (Crustacea: Mysidacea) following chlorpyrifos exposure: a method comparison. Journal of Experimental Marine Biology and Ecology, 306(1), 1-16. http://dx.doi.org/10.1016/j.jembe.2003.12.022

Walker, A. N., Bush, P., Puritz, J., Wilson, T., Chang, E. S., Miller, T., et al. (2005). Bioaccumulation and metabolic effects of the endocrine disruptor methoprene in the lobster, Homarus americanus. Integrative and Comparative Biology, 45(1), 118-126. http://dx.doi.org/10.1093/icb/45.1.118

Walker, A. N., Golden, R., \& Horst, M. N. (2010). Morphologic effects of in vivo acute exposure to the pesticide methoprene on the hepatopancreas of a non-target organism, Homarus americanus. Ecotoxicology and Environmental Safety, 73(8), 1867-1874. http://dx.doi.org/10.1016/j.ecoenv.2010.08.013

Weber, J., Halsall, C. J., Muir, D., Teixeira, C., Small, J., Solomon, K., et al. (2010). Endosulfan, a global pesticide: a review of its fate in the environment and occurrence in the 
Arctic. Science of the Total Environment, 408(15), 2966-2984. http://dx.doi.org/10.1016/j.scitotenv.2009.10.077

White, L. M., Ernst, W. R., Julien, G., Garron, C., \& Leger, M. (2006). Ambient air concentrations of pesticides used in potato cultivation in Prince Edward Island, Canada. Pest Management Science, 62(2), 126-136. http://dx.doi.org/10.1002/ps.1130

Wirth, E. F., Lund, S. A., Fulton, M. H., \& Scott, G. I. (2001). Determination of acute mortality in adults and sublethal embryo responses of Palaemonetes pugio to endosulfan and methoprene $\quad$ exposure. Aquatic Toxicology, $\quad$ 53(1), http://dx.doi.org/10.1016/S0166-445X(00)00157-0

Wu, J.-P., Chen, H.-C., \& Huang, D.-J. (2008). Histopathological and biochemical evidence of hepatopancreatic toxicity caused by cadmium and zinc in the white shrimp, Litopenaeus vannamei. Chemosphere, 73(7), 1019-1026. http://dx.doi.org/10.1016/j.chemosphere.2008.08.019

Xing, Z., Chow, L., Cook, A., Benoy, G., Rees, H., Ernst, B., et al. (2012). Pesticide application and detection in variable agricultural intensity watersheds and their river systems in the Maritime Region of Canada. Archives of Environmental Contamination and Toxicology, 63(4), 471-483. http://dx.doi.org/10.1007/s00244-012-9789-9

Yadwad, V. B. (1992). Effect of endosulfan on lipid synthesis by the hepatopancreas of thefield crab Paratelphusa hydrodromus. Journal of Environmental Science \& Health, Part A: Environmental Science \& Engineering, A27(7), 1987-1995

Zaldibar, B., Cancio, I., \& Marigomez, I. (2007). Reversible alterations in epithelial cell turnover in digestive gland of winkles (Littorina littorea) exposed to cadmium and their implications for biomarker measurements. Aquatic Toxicology, 81(2), 183-196. http://dx.doi.org/10.1016/j.aquatox.2006.12.007

Zar, J. H. (1996). Biostatistical analysis (3rd ed., p.662). New Jersey.

Zorita, I., Ortiz-Zarragoitia, M., Soto, M., \& Cajaraville, M. P. (2006). Biomarkers in mussels from a copper site gradient (Visnes, Norway): an integrated biochemical, histochemical and histological study. Aquatic Toxicology, 78, Supplement(0), S109-S116. http://dx.doi.org/10.1016/j.aquatox.2006.02.032

Zulkosky, A. N. N. M., Ruggieri, J. P., Terracciano, S. A., Brownawell, B. J., \& Mcelroy, A. E. (2005). Acute toxicity of resmethrin, malathion and methoprene to larval and juvenile American lobsters (Homarus americanus) and analysis of pesticide levels in surface waters after Scourge, Anvil and Altosid application. Journal of Shellfish Research, 24(3), 795-804. http://dx.doi.org/10.2983/0730-8000(2005)24\%5B795:ATORMA\%5D2.0.CO;2

\section{Glossary}

AMR Active metabolic rate $\left(\mathrm{mg} \mathrm{O}_{2} \cdot \mathrm{h}^{-1} \cdot \mathrm{g}^{-1}\right)$

$\mathrm{AMR}_{\mathrm{g}} \quad$ Specific AMR $\left(\mathrm{mg} \mathrm{O} \cdot \mathrm{h}^{-1} \cdot \mathrm{g}^{-1}\right)$ 


\section{Macrothink}

$\mathrm{AMR}_{0.1 \mathrm{~g}} \quad$ AMR standardized to a $0.1 \mathrm{~g}$ juvenile lobster $\left(\mathrm{mg} \mathrm{O}_{2} \cdot \mathrm{h}^{-1} \cdot \mathrm{g}^{-1}\right)$

CL Cephalothorax length (mm)

$\mathrm{CL}_{\mathrm{i}} \quad$ Initial or premolt cephalothorax length (mm)

$\mathrm{CL}_{\mathrm{f}} \quad$ Final or post-molt cephalothorax length (mm)

IP Intermolt period (days)

M Wet mass (g)

MI Moult increment $\left(\%\right.$ of $\left.\mathrm{CL}_{\mathrm{i}}\right)$

$\mathrm{MO}_{2} \quad$ Oxygen consumption $\left(\mathrm{mg} \mathrm{O}_{2} \cdot \mathrm{h}^{-1} \cdot \mathrm{g}^{-1}\right)$

MR Metabolic rate $\left(\mathrm{mg} \mathrm{O}_{2} \cdot \mathrm{h}^{-1} \cdot \mathrm{g}^{-1}\right)$

MS Metabolic scope $\left(\mathrm{mg} \mathrm{O}_{2} \cdot \mathrm{h}^{-1} \cdot \mathrm{g}^{-1}\right)$

RMR Routine metabolic rate $\left(\mathrm{mg} \mathrm{O}_{2} \cdot \mathrm{h}^{-1} \cdot \mathrm{g}^{-1}\right)$

SfG Scope for growth

SGR Specific growth rate

SMR Standard metabolic rate $\left(\mathrm{mg} \mathrm{O}_{2} \cdot \mathrm{h}^{-1} \cdot \mathrm{g}^{-1}\right)$

$\mathrm{SMR}_{\mathrm{g}} \quad$ Specific SMR $\left(\mathrm{mg} \mathrm{O}_{2} \cdot \mathrm{h}^{-1} \cdot \mathrm{g}^{-1}\right)$

$\mathrm{SMR}_{0.1 \mathrm{~g}} \quad \mathrm{SMR}$ standardized to a $0.1 \mathrm{~g}$ juvenile lobster $\left(\mathrm{mg} \mathrm{O}_{2} \cdot \mathrm{h}^{-1} \cdot \mathrm{g}^{-1}\right)$

\section{Copyright Disclaimer}

Copyright reserved by the author(s).

This article is an open-access article distributed under the terms and conditions of the Creative Commons Attribution license (http://creativecommons.org/licenses/by/3.0/). 